\title{
Getting to the Heart of Cultural Safety in Unama'ki: Considering kesultulinej (Love)
}

\author{
De-Ann Sheppard \\ Cape Breton University
}

Cite as: Sheppard, D. M. (2020). Getting to the Heart of Cultural Safety in Unama 'ki: Considering kesultulinej (Love). Witness: The Canadian Journal of Critical Nursing Discourse, Vol 2 (1), 51-65 https://doi.org/ 10.25071/2291-5796.57

\begin{abstract}
Reflecting upon my early knowledge landscapes, situated within the unceded Mi'kmaq territory of Unama'ki (Cape Breton, Nova Scotia), living the Peace \& Friendship Treaty and the teachings of Mi'kmaw Elders, I contemplate the essential relationship with land and language, specifically, kesultulinej (love as action) and etuaptmumk (two-eyed seeing) to Cultural Safety. I recognize my position, privilege, and Responsibility in teaching and learning about the contextual meanings of Cultural Safety, situated in specific Indigenous terrains and in relation with the land, across time, and relationships. Critical reflection on my story and experiences challenge me to consider why and how Maori nursing theorizations of Cultural Safety have been indoctrinated into the language of national nursing education by the Canadian Association of Schools of Nursing (CASN), Canadian Nurses Association (CNA) and most provincial nursing regulatory bodies; this is increasingly relevant as nursing education is progressively shaped by neoliberal and Indigenizing agendas. As I contemplate wrapping Cultural Safety with kesultulinej, I see the potential to decolonize nursing. Mi'kmaw teachings of etuaptmumk and kesultulinej call forth Responsibilities to act, and in doing so move us into a space of potential to resist the colonizing forces within nursing. In this moment I realize the interconnected meaning of being amidst these relationships that matter to me as a person and as a nurse; relationships that are marked by love, care and compassion.
\end{abstract}

Keywords: Cultural Safety, decolonizing nursing, Indigenous nursing, love as action, nursing education 


\section{Getting to the Heart of Cultural Safety in Unama'ki: Considering kesultulinej (Love)}

In one of my first conversations with Elder Albert Marshall he described knowledge as a living garden with a learning spirit. I The way he described knowledge as being alive and having its own curious essence resonated with me. I have come to appreciate how despite having heard Elders stories repeated numerous times, consistently something new emerges in my being, shifting my perspective as they teach. Wise Knowledge Holders and teachers plant seeds of knowledge, often without our conscious awareness, not knowing when or how the germination process will unfold. They have patience and trust that when ready, the seed will grow into the persons knowledge garden. Listening to him, I wondered what knowledge might be awakening inside me. Acquiring knowledge is essential to my work as a nurse practitioner I've always been interested in patients' stories of what mattered most to them in their healing journeys, and how they come to know the experience of care. Elder Albert shared with me some of his encounters with the healthcare system. While he might agree with me if I described his experiences as racist, he would not choose this language. We both recognized these experiences as everyday occurrences for Mi'kmaq in mainstream healthcare and awareness of that reality is mutually troubling. I felt his frustration when he declared, "I shouldn't have to legislate love, legislate care and compassion" (personal communication, June 6, 2018). When he initially drew my attention to love, care and compassion, I didn't really appreciate what he was telling me and almost missed it. It is only now, that I realize that in that moment he gave me much to think with. Our conversations deepened as our relationship grew and he would often pose rhetorical questions to me. Questions such as: "Why do you think L'nu nurses return to their communities the first chance they get?" 2 Uncertain I would try to answer the question: "could it be the racism, or discrimination they

\footnotetext{
${ }^{1}$ Mi'kmaw Elder from Eskasoni First Nation renowned for his conceptualizations of Etuaptmumk, two-eyed seeing and co-developer of the Integrative Science Program and Cape Breton
}

face, or the colonized systems, policies and regulations they must adhere to in practice?" I would later learn that he wasn't asking my thinking mind, rather engaging my whole being, awakening the curiosity of the learning spirit. I waited for his response. "Anyway..." he says and eventually the conversation circled back to love, care and compassion. Within this critical context I had not considered the discourse of love as action. I had to catch a deep breath, taking a moment to integrate this new seed of knowledge, pondering how it might grow. It took time for me to learn to be patient and to sit with the discomfort and confusion these conversations generated for me. I had to learn to trust in processes that allowed knowledge to germinate. Looking back, it is in these moments that I become closer to the heart of what matters. (Elder Albert Marshall, Mi'kmaq, Eskasoni, these co-learning conversations began in May of 2017 and continue on Mi'kmaq Ancestral territory in person, over the phone and occasionally by email when he considers and gives feedback on my writing.)

\section{Turning to my Stories}

How do I decolonize my mind and bring my whole being, allowing the learning spirit to lead, as I become closer to the heart of what matters? Where do my story and lived experience fit? My experience of leaving home (never to return) for education, working for 11 years as a Registered Nurse, followed by 22 years as a Nurse Practitioner in rural and remote Indigenous communities. The suffering associated with this disconnection and dislocation and the innate longing to reclaim and reconnect with my kinship, stories and teachings lies lurking in the backdrop. My 22year healing journey of reclaiming my Indigeneity is part of my experience and how I continue to grapple with the tension of being a woman of Mi'kmaq and Irish descent. The collective Responsibility I now shoulder is unmistakable, as I bear the weight of

University. From this point forward I will refer to him simply as Elder Albert.

2 The term Mi'kmaq is used to refer to themselves, and loosely translates to people of the land. 
community expectations, intensified by the radical hope of Elders to move the Indigenous health agenda forward, and to ultimately improve the health of $L^{\prime} n u$ in Unama'ki. How can I plant seeds of knowledge in ways to foster and grow new knowledge gardens? Gardens to which love, care and compassion are central? Reflecting on this question I look back and recall my teachers of love. I am reminded of my early knowledge landscapes and teachings of the importance of introducing who I am, where I come from and where I am going on the path of life (Cajete, 1994).

\section{(Re)membering Home}

My name is De-Ann Sheppard and I am from Labrador. My father, Greg, is from St. George's, Newfoundland and was raised in a Mi'kmaw Catholic home, while my mother, Mary, is from Bell Island, Newfoundland and was raised in an Irish Catholic home. The oldest daughter of four girls, I am a mother to two sons with big hearts. I am also a partner, friend, grandmother, aunt, nurse practitioner, nurse educator, $\mathrm{PhD}$ student, peer mentor and emerging scholar. My daily intention is to lead a life of gratitude, guided by my heart and that all thoughts, acts and deeds are done with integrity. In my heart I carry my teachings, stories and wisdom. My true work is to be an active presence, share my gifts, and to facilitate research and learning in a healing way, to create spaces where we feel inspired and to be brave while feeling safely held at the same time.

The Algonquins of Pikwàkanagàn welcomed me into my first Nurse Practitioner position, a rural satellite clinic of the Wabano Centre, situated in Golden Lake, ON. My instructions were to establish a primary health care clinic, specifically with the intention of integrating western medicine with traditional medicine. This privileged me to work and study with Mi'kmaw Elder and Medicine Woman, Sagaligesgw (Plant Woman), Jeorgina LaRocque. I tear up when I recall my first heart piercing encounter, she embraced me, wrapped in what I can only describe as an unconditional loving presence that I had never felt before. This was my invitation to reclaim my stories, healing practices, ceremonies and the power of recovering my identity. It profoundly shaped my worldview as a nurse practitioner and faithfully grounded, what I now call etuaptmumk (two- eyed seeing), into my being. Building on this foundation, I grew my primary care expertise and confidence over the following decade. As such, I felt competent when I assumed my role as the Director of Patient Care in the remote First Nation community of Attawapiskat, Ontario. Yet, somewhere in the midst of Chief Theresa Spence's protest for community resources, and subsequent hunger strike, the grassroots emergence of Idle no More, the protest that blocked the ice road to Victor mines, three states of emergency called in six months, and a tragic helicopter crash, I realized my ineptitude. These dire experiences taught me how crucial culturally safe practices, which are guided by love, care and compassion, are to the health and well-being of a community. Humiliated and exhausted I retreated to embark on a different learning and healing journey. I hold deep gratitude for this experience of desperate powerlessness, it broke open my heart, as it awakened me to knowledge and strength, I forgot I had.

\section{Revisiting Elder Albert's Words}

Mi'kmaw worldviews that understand love, care and compassion have called me to return home to the Teachings of Elder Albert. As I revisit his words, I also begin to see the importance of place, the connections to lands generative nature and the language land speaks - love, care and compassion is contextual and situated in particular places and relationships. The Canadian Indigenous Nursing Association (CINA) describes Indigenous health nursing scholarship as "a genuine search for a new way of nursing and the challenges and benefits it presents for clients and populations born of social, physical, economic, political, historical and cultural realities [Indigenous People] want to be faithfully reflected in nursing care" (ANAC, 2001, p.40). As I contemplate how this understanding shapes my nursing practice, I begin to feel a shift in my knowledge garden - in my turn towards practice, I turn towards love and care. Love as both a concept and a practice has previously been explored (McGregor, 2012; Simpson, 2013; hooks, 2001). Indigenous theorizations of love describe a communal 
loving responsibility, interdependence, and interconnectedness. "As Native scholars, whose teachings include love, our writing and our work is influenced by the love of our people and all of creation. This love will always be there" (Whiteduck, Algonquin, 2013, p.89). It is essential as you read that you understand the nature of the colonized political correctness of the term Indigenous Peoples: a problematic categorization of our First Peoples of North America and their descendants, consisting of Indians (First Nations), Métis, and Inuit. Careful attention is required when using this terminology as it risks assimilation and erasure of the plurality and diversity of cultures of First Peoples. Leanne Betasamosake Simpson, Anishinaabe, (2013) describes her search to decolonize love: " $[t]$ he kind of love I was interested in, could liberate [us] from that horrible legacy of colonial violence. I am speaking about decolonial love $[\ldots]$ is it possible to love one's broken-by-thecoloniality-of-power self in another brokenby-the-coloniality-of-power person?" (p. i). My mentor and Mi'kmaw Elder Stephen Augustine describe kesultulinej (love), as a verb in the Mi'kmaw context, as action and not to be confused with the English word love. "In Mi'kmaw language, the word is not self-serving; it is more a collective/communal love that includes respect, dignity, and pride for the whole community and seven generations ahead" (personal communication, May 23, 2019).

I hold a deep respect and

Responsibility to the stories and teachings I have received. The reciprocal nature of these teachings come out of relationships and have contextual meaning unique to those relationships. Much of what I know, I cannot share without this connection. As I think and write about kesultulinej, I asked Maliseet Elder Ken Paul, a Knowledge Keeper of the Teachings of love, if I could share these with others. He felt I should hold back most of what I had come to learn from him, as he was not there to ensure that others, like readers of this paper would be ready. I might confuse you, in my attempt to write about love, care and compassion. Yet, while cautioning me, Elder Ken Paul at the same time, encouraged me to say, "the most important steppingstones that you can build from, is the spiritualemotional-physical-mental link to the cultural-social-economic-political aspects of society" (personal communication, May 6th, 2019). My understanding of his teachings is that we achieve love when the intersections of all society domains are in balance. Love as action therefore requires a much broader worldview of a person's physical, mental, emotional, and spiritual health. I return to Elder Albert's question. Were L'nu nurses relieved to leave behind the institutional violence and return to their communities? Reconnecting to land and language, where they are safe to be themselves, free to embody kesultulinej? Was this true for all nurses?

\section{Turning towards etuaptmumk (two-eyed seeing)}

Thinking back to my time in Attawapiskat, remembering the overwhelming sense of futility, I return to my conversations with Elder Albert. I lean into a relational space of possibility Elder Albert calls etuaptmumk (two eyed seeing) to become closer to the heart of what matters.

Etuaptmumk, like all Mi'kmaw language, arises from the land and our relationship to all creation. There is an embedded assumption that values the ability to simultaneously access multiple perspectives. When considering a way forward, Elder Albert describes bringing together his Mi'kmaw worldview and inviting in the Eurocentric scientific worldview, looking for strengths and potential synergy for action. Sometimes he muses that 'its common sense really'. It is in those moments that my being feels the uncertainty, and I return to my story and I am able to see how this Indigenous relational interconnected epistemology is counterintuitive and challenging for colonized minds, including my own. I am learning the nuances and complexity of this concept and continue to deepen my understandings of this Knowledge and always defer to my Elder for Teachings. It is with Elder Albert's permission that I am ready to carry the Responsibilities of sharing my experiences of my decolonial untangling etuaptmumk moments. Elder Albert 
reminds me regularly that there is always another way.3

This space has been theorized by other Indigenous scholars as "ethical space" (Ermine, Cree, 2007), cultural interface (Nakata, Torres Strait Islander 2006 \& 2007) and cultural hybridity (Chulach \& Gagnon, 2016). While conceptually different, there is agreement that this is a powerful space that values the importance of multiple perspectives and requires respectful navigation. Considering the fluidity and the veil-like thinness of this relational space as I sit in the unceded territory of Unama'ki (Cape Breton), the place of fog and first light, I am reminded of the Teachings of the sunrise, and how that space, thinner than a strand of hair, holds so much potential. Cultural hybridity acknowledges this is a challenging place to be, the site of the active construction of professional identity and agency, and a counter strategy to colonial authority (Chulach \& Gagnon, 2016). Moreover, this is the space of potential where one feels either the invisibleness and erased self-presence or the reclamation of identity and agency. The latter is where love, care, and compassion matter most. Given that love is seen as action, it requires a relational space - love, if understood as action calls forth response and Responsibilities. This relational space holds great potential for Indigenous nurses to work within multiple worldviews, their ability to hold the paradox of the colonial shame and Indigenous Pride, with kesultulinej as the balancing medicine. Coming full circle, over and over, I return to kesultulinej.

\section{My Disruption}

McCallum and Perry's (2019)

Structures of Indifference: An Indigenous Life and Death in a Canadian City, painstakingly force our attention to the detailed account of the last 36 hours of an Indigenous man's life in a Canadian institution of care. The authors incorporate Razack's terminology of "casual inhumanity" and "deep disregard for

\footnotetext{
3 This Responsibility is understood by Indigenous scholars. The decision to write instantaneously places you at a delicate crossroad of tension holding the possibility to be either the colonizer, the colonized or both. Cash Richard Ahenakew, Cree, (2017) uses the metaphor of grafting
}

Indigenous life" (p.127), to describe how innocently Indigenous racism is embedded and normalized in everyday contemporary Canadian reality. Brian Sinclair's Anishinaabe presence remained invisible for 36 hours, as he died in plain sight in the emergency room waiting area of the Winnipeg Health Sciences Centre (McCallum \& Perry, 2018, p.127). Despite repeated concerns voiced by patients and families, security, housekeeping, nurses, and a nursing student, all failed in their duty to care for Brian Sinclair as he sat dying in his wheelchair. Biased assumptions that normalize Indigenous Peoples as intoxicated, homeless, and needing to sleep it off in the department, allowed moral actors to perform everyday racist behaviour (Browne, 2017 \& Allan \& Smylie, 2015). How did we get here? What are we prepared to do to make this stop? What if they had understood zahgidiwin

(Anishinaabe word for love) as action that calls forth Responsibilities?

\section{Cultural Safety}

As I think about what could have been otherwise, I think about how Cultural Safety, raised hope to disrupt the status quo and the language to articulate the inherent danger and political nature of the change required to provide safe spaces of care for and with Indigenous Peoples. Maori Scholar, Irhapeti Ramsden (2002), answered the call of her People and wrote prolifically about this nursing concept, Cultural Safety. Accepting Responsibility to commit to what communities asked for, to protect Maori nurses in their places of education and practice, she ensured that the community retained the power to define and evaluate Cultural Safety (Ramsden, 2002). Yet, in Canada, theorizations of Cultural Safety have not created the urgency or activated the anticipated social justice response from nursing (Browne, 2017 \& Allan \& Smylie, 2015). I often wonder if this lack of response signals a lack of love and understanding? Is this how nurses live their Responsibility? Experienced transformative

Indigenous Knowledge. Etuapmumk has been transplanted into health research. If our readers are not ready to consider relationality, to suspend for a moment the certainty their knowledge is complete, then these seeds of knowledge may end up genetically modified and patented. 
educators who draw from anti-racist pedagogy describe ideologies of multiculturalism, meritocracy and innocence that are embedded in the consciousness of Canadians, yet evidenced in their classroom note experiences of significant resistance to change (Schick \& St. Denis, 2005; Ward, Branch \& Fridkin, 2016). How has Cultural Safety education in nursing classrooms addressed this resistance? Feminist Minnie Bruce Pratt (1983) asks: Why and when does a person willingly undertake change, especially if one is materially and ideologically safe and comfortable? What does one stand to gain from questioning one's cherished beliefs and changing fundamental ways of thinking? (p. 16)

As a nurse motivated by love, I can no longer turn away from the questions asked by Pratt nor from experiences like those of Brian Sinclair. Pratt's questions have not only challenged me to look at who I am and the assumptions I hold/have held, but have challenged researchers across disciplines, social psychologists and critical post-colonial feminist theorists, to ask ourselves difficult questions. Faced with these challenges holding, multiple perspectives, it is clear that there is not a single strategy to awaken peoples' sense of Responsibility and kesultulinej. Building on the 1845 social analysis of Engels, Chernomis and Hudson (2010) describe policies that intentionally fail to provide access to basic human needs such as food, clean drinking water, or healthcare while simultaneously removing hope, dignity, and a shared common purpose create inequality equivocal to social murder. This analysis also demonstrates the roots of some of the conceptualizations of the lower class and Darwinist thinking to be rid of "the Indian problem" (Government of Canada, 1969). Is the experience of inequity of Canada's Indigenous Peoples, not only a failure to love and care, but also intentional social murder? Why is there no sense of urgency or action to attend to the body of Brian Sinclair, in moments where his Indigenous presence simultaneously occupies the spaces nurses work? Are we asking too much? How do we mobilize love and care? How do we compel a readiness to respond differently, take risks even when we are uncomfortable and even afraid? How do we become willing to lean into what matters most? If we become kesultulinej we can work backwards to answer these questions and live our communal

Responsibility in ways that create and ensure Indigenous futurities.

Respect for the lifelong Responsibility and commitment of Maori nursing scholar Dr. Irihapeti Ramsden to Cultural Safety, and recognition of this gift to nursing, must be reciprocated with our continuance. Ramsden's (2002) doctoral dissertation chronicles two decades of the New Zealand nursing collaborative journey and growing Cultural Safety consciousness. Sharing both public and personal narratives, she modeled a steadfast kesultulinej (love as action) as her Indigenous theory, methodology and framework. This was specifically achieved by grounding Cultural Safety in reciprocal relationship with the land, language and the Treaty of Aotearoa and Te Waipounamu. Appreciating the power and perceived threat of Cultural Safety to disrupt colonizing forces, Ramsden's community was fearful for its future in nursing. Is this fated forecast being realized in the Canadian healthcare landscape? Ramsden's (2002) use of Reflective Topical Autobiography to critically (re)tell her story of reclaiming her gifts as a transformative healer and educator, using self-research as a vehicle to lead us to new consciousness and insights, while consistently challenging the inherent indifference, dismissive ignorance and arrogance housed in the convenience of colonialism, provides both inspiration and a map. Radical hope to change Indigenous futurities is inspired by the following poem "A Ritual to Read to Each Other":

If you don't know the kind of person I am and I don't know the kind of person you are a pattern that others made may prevail in the world

and following the wrong god home we may miss our star.

For there is many a small betrayal in the mind, a shrug that lets the fragile sequence break sending with shouts the horrible errors of childhood

storming out to play through the broken dike. 
And as elephants parade holding each elephant's tail,

but if one wanders the circus won't find the park,

I call it cruel and maybe the root of all cruelty to know what occurs but not recognize the fact.

And so I appeal to a voice, to something shadowy,

a remote important region in all who talk: though we could fool each other, we should consider-

lest the parade of our mutual life get lost in the dark.

For it is important that awake people be awake,

or a breaking line may discourage them back to sleep;

the signals we give - yes or no, or maybe -

should be clear: the darkness around us is deep.

(Stafford, 1998, p. 76)

As I sit in Wabanaki (the people of the dawn), the place of first light, living the Treaty of Peace and Friendship, I consider Ramsden's gift of Cultural Safety and what she has awakened in my being. In this moment, I open my heart and allow myself to welcome her learning spirit into mine and I feel less alone. She has awakened a deeper knowing of kesultulinej and etuaptmumk, along with a curiosity of how the seed of Cultural Safety might emerge if grown here in this land.

How do we remain awake and accountable to ground Ramsden's gift to nursing in the Canadian nursing colonialscape? "The merit and [significance] of Cultural Safety is wellestablished and its [necessary] role in the delivery of healthcare increasingly accepted" (Guerra \& Kurtz, 2017, p. 140). While consideration of Cultural Safety in Canadian nursing literature has significantly increased with the Calls to Action of the Truth and Reconciliation Commission (2015), the simultaneous pressure on Canadian academies to Indigenize curriculum has resulted in predominantly Indigenous inclusion policy rather than treaty-based decolonizing action (Gaudry \& Lorenz, 2018). What are the ramifications of such rapid and broad implementation without contextual incorporation of Indigenous worldviews, honoring relationship to land and incorporation of treaties? What has been lost in translation? What has been silenced? Despite clear conceptual delineation, Cultural Safety continues to be utilized interchangeably with cultural competence. Indigenous Knowledges are located in specific places, contexts, and across time. It is here that love, care and compassion become secondary and are devalued. It is here that we silence the voices of Elders and communities. In this silence, the travesty of Cultural Safety being described as "a strategy in high-income English-speaking countries in response to evidence of health disparities, structural inequalities, and poorer quality health care and outcomes [in minority groups...], a paucity of evidence to [...specific] outcomes" harms my resolve (Horvat, Horey, Romios, \& Kis-Rigo, 2014, p. 7). It is in this darkness I extend myself care and compassion and I remain awake.

The challenges faced by Canadian institutions responsible for credentialing nurses in the context of neoliberal knowledge production are exacerbated by the TRCs (2015) Calls to Action, and more specifically to number 24:

We call upon medical and nursing schools in Canada to require all students to take a course dealing with [Indigenous] health issues, including the history and legacy of residential schools, the United Nations Declaration on the Rights of Indigenous Peoples, Treaties and Aboriginal rights, and Indigenous teachings and practices. This will require skills-based training in intercultural competency, conflict resolution, human rights and anti-racism (p. 3).

These calls have startled the nursing consciousness creating a new appetite for all things Indigenous and a continuum of responses across schools of nursing in Canada. The spectrum of these Indigenization responses is described by Gaudry \& Lorenz, (2018) as a minimum Indigenous inclusion (I would argue exclusion) moving progressively towards reconciliation and decolonial Indigenization. Their research demonstrated consistent themes from Indigenous scholars in 
the academy voicing their concerns of balancing the potential for self-determination and sovereignty of Indigenous nation's resources with the real threat that superficial policies without changes in governance and balancing of power could further strengthen colonialism. Moreover, participants in Gaudry \& Lorenz's (2018) study emphasised that Indigenous bodies in academic institutions with inclusive Indigenization policies felt unsafe in these hostile spaces and the invisible messaging that their full Indigenous presence, including epistemological and ontological assumptions, are best left at the door.

The narrative of Canada's universal healthcare system as struggling to meet the demand for healthcare dominates many conversations and often further marginalizes the voices of those who require more from the system. The turbulent context of neoliberal education policy in Canada and the erosion of the preparation of nursing graduates must not be ignored in this conversation - the focus becomes one that recognizes outcomes, and dismisses processes (Goodman, 2014). This shift creates unique challenges for nurse educators to understand and teach Cultural Safety (Doran, Wrigley \& Lewis, 2019). This difficulty is accentuated at a time where universities are being encouraged to expediently produce practice ready nurses, with incentives to offer advanced entry and compressed nursing programs. It is in these moments where I wonder: Where are the spaces and places for nurses to learn about kesultulinej and about etuaptmumk, concepts central to furthering our understanding of what Culturally Safe practices look like at the bedside, in the home or in the community? When we incorporate Cultural Safety into practice standards, what do we really mean? How does nursing as a profession understand this Indigenous theorization to both educate and evaluate nurses to provide Culturally Safe care?

In 2015, asserting improved patient safety, nursing regulators across the country (excluding Quebec and New Brunswick) made changes to Canada's nursing entrance requirements from a Canadian to an American exam: NCLEX-RN. Not only did this result in the absence of Cultural Safety indicators but further supports the neoliberal policy of commodifying and marketing professions to creating requirements to standardize evaluation and legitimize nursing knowledge (Foth \& Holmes, 2016). This initially resulted in failure rates of up to $30 \%$ (specifically impacting diverse student populations, Indigenous and Francophone students), delaying graduate nurses' entry into practice, and critique from then CASN president Kristen Woodend (2016). Although there is denial, curriculum has adjusted to teach to the test. NCLEX scores now significantly influence how individual nursing programs are evaluated while nursing students contribute to a multi-million-dollar industry. This is only one example but teaching students to conform to systems that oppress and dehumanize patients without the skills of critiquing their everyday realities leads to "disempowerment, disillusion and disengagement of nurses" (Goodman, 2014, p.1055). It is here that we must place and accept responsibility for the death of Brian Sinclair and the absence of kesultulinej.

Accountable nursing education, models Ramsden's teaching philosophy and embraces transformative nurse educators as transformative healers. This requires a commitment to weave decolonized spaces into the everyday places throughout the curriculum. Decolonized nursing education, informed by anti-racist and transformative pedagogy, unpacks the invisible skill set required for Cultural Safety and provides students with the skills to challenge the status quo, raising critical awareness of bias, and the cultural courage to step into spaces that include Indigenous presence. Brian Sinclair is seen. As I struggle to find ways forward and to make sense of the inequities I have seen in Attawapiskat, I am reminded of Elder Albert's teachings, as well as Ramsden's work on Cultural Safety. Ramsden's concerns about nurses being seen as doers not thinkers remain a challenge. How do we, as nurses, remain awake, re-engage and gain the critical thinking and political skills necessary to articulate what we do and demonstrate that our knowledge matters? 


\section{Considering Kesultuline (love as action)}

Indigenous nurses embody the tension of living at the intersection of nursing in a colonized healthcare system as a site of resistance and social change, balanced with the awareness of the everyday colonizing forces of the profession to assimilate. The ability to navigate multiple perspectives simultaneously is where Indigenous nursing knowledge and ways of knowing will allow for the creation of a contextualized, treaty informed, decolonized nursing curriculum. The strengths, achievements and unique contributions of Indigenous nurses are often underappreciated or misunderstood by those who are not directly involved in healthcare and sometimes even by those who are, including the nursing profession (McCallum, 2014). Illuminating Indigenous nursing perspectives focuses our attention, creates a space of potential and opportunity for the exploration of the complex role that nurses play in the individual and collective health of their communities. It is precisely the ability Indigenous nurses have of leaving parts of themselves at the door as they enter educational and practice setting, respecting multiple perspectives and the unconscious competence they demonstrate as they do this that models etuaptmumk. The ability to navigate knowledge systems that are epistemologically incommensurable holds the key. This struggle with incongruence is illustrated by artist Nicole Hawkins (2018):

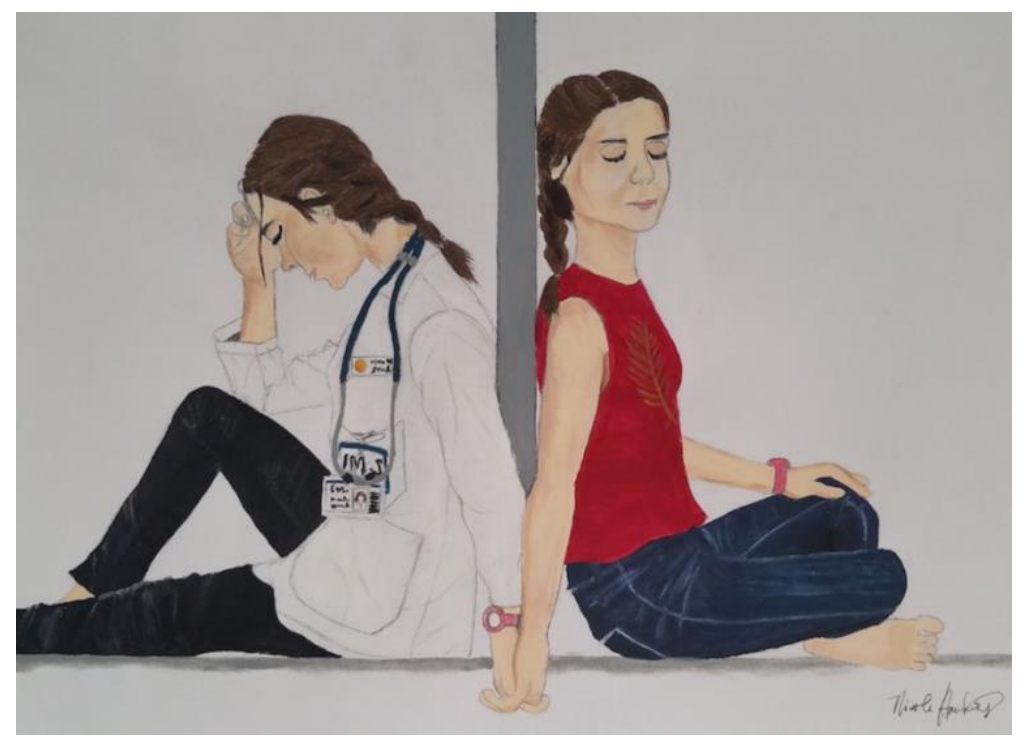

Figure 1. 'Self-Preservation' by Nicole Hawkins (2018) with permission.

The profession of nursing, despite being recognized as a colonizing force, is embraced by Indigenous nurses as a site of resistance as they shoulder the Responsibility of decolonizing healthcare. Moreover, Canadian Indigenous Nurses Association past President Lisa Bourque Bearskin (2016) adds the following in context of reconciliation,

The wisdom of [...] Indigenous nurses teaches us that all Canadians - and every nurse - can engage in relationships at the personal, professional and political level that are authentic, reciprocal and meaningful if the steps of listening, knowing, being and doing are followed. (p. 36)

Creating contexts, times, and places to listen and appreciate the complex sociopolitical contexts and colonized structures Indigenous nurses negotiate will allow for imagining what action will be required to support nursing practice that recipients of care decide is Culturally Safe. It will create maps for navigating worlds with loving perceptions, so we can authentically and honestly travel to the heart of what matters. I understand that the personal is political and to enter this conversation at this 
moment it is important to mindfully consider the colonized, gendered, and racialized spaces my Indigenous body occupies. My positionality as a nurse practitioner, professor, and researcher, as a heterosexual female conforming to a hegemonic gender binary, and phenotypically I pass for white, all hold potential for disruption of power perceptions. I am originally from Newfoundland and Labrador, and while welcomed as one of their own I consistently and specifically locate myself as a guest in Unama'ki. Positioning myself from this place of dislocation and disconnection also serves as a reminder that I am not a fluent Mi'kmaw speaker. Simultaneously, as an Indigenous nurse I am called by our Elders to engage with the learning spirit in ways that can grow knowledge gardens within myself, my communities, and those with whom I engage with on a daily basis.

\section{Answering the Call}

It's mid-afternoon on November 15 th, 2019. I can no longer procrastinate. I am being called to commit to writing about what matters to me. I am terrified and yet I am compelled to write as there is a dissonance growing inside of me; a feeling of dis/ease. Indigenous feminist scholar Dian Million (2009) challenges me to consider my feelings as theory "[My feelings] are [my] frames and no two of us can 'see' them distinctly the same way $[. .$.$] thus our feelings [. .$.$] are important$ projections about what is happening in our lives. They are also culturally mediated knowledges, never solely individual" (p. 61). As I write this paper, I am humbled by the steadfast determination and commitment of the growing number of Indigenous nurses and scholars and the current ground-breaking scholarship happening around the globe and their resolve to resist/persist forevermore. Ramsden's (2002) scholarship beckons us to be brave and speak up. Theorizing a framework for nursing grounded in kesultulinej, means centering Indigenous Knowledges in all that I do. Ramsden established Indigenous nursing scholarship in a new paradigm as she recognized that transformative change started with her. Using reflective topical autoethnography, she acknowledges her personal story, her knowledge garden, as teacher. Ramsden models love and courage in her lifelong commitment to act in relationship, as she makes visible her nuanced understanding of Cultural Safety. As I witness and learn from her story, I know my story matters and has something to teach. I have a Responsibility to love also who I am. Leanne Betasamosake Simpson's, (2013) poetry reminds me of how important this is:

For everyone of your questions there is a story hidden in the skin of the forest, use them as flint, fodder, love songs, medicine, you are from a place of unflinching power, the holder of our stories, the one who speaks up

The chance for spoken up words drowned in ambush

You are not a vessel for white settler shame,

Even if I am the housing that failed you (p. 132)

Sharing my story feels dangerous and necessary. It feels both like the right thing to do while simultaneously breaking the code of silence. Holding these opposing ideas with kesultinej as they enter into our consciousness, our conversations, using etuaptmumk to respectfully hold these ideas without dismissing the most inconvenient ones, we make ourselves resilient and strong. In that light, I share the link to my video story of my journey home as kesultultinij (Sheppard, 2019): https://vimeopro.com/user20653208/cbu

\section{Returning to home}

I take a deep breath as I am being called back to the land in Unama'ki. "The land knows you even when you are lost" (Kimmerer, 2013); it is the land, the sea that know me, invite me repeatedly to be found again and again. Amswekewe (How it was/How it is/How it will always be) makes it possible for me to return. I am called to reconnect with the land and language of Mi'kma'ki. The welcoming spirit, love and genuine friendliness of the Mi'kmaw communities inspire me and feed my mind, body and spirit. A community of engaged, creative and enthusiastic Mi'kmaw nurses 
exemplify kesultulinej in the communities they serve. As our relationships grow, I look forward to supporting their research visions, inviting their expertise into our classrooms and learning how to become closer to what matters most. My grandmother Rose spent Sunday afternoons admiring pictures of her grandchildren and great grandchildren, marveling "Isn't a human being's capacity to love amazing, just when you thought your heart couldn't stretch any further, you discover it can". I do this to strengthen our capacity for kesultulinej. The healing, decolonizing, reconciling and liberating nature of this work starts with me and my kinship relationships. Coming home to a place of love, care and compassion, is a way to live and breathe my Responsibilities and the possibilities nursing holds if we listen closely, if we notice Brian Sinclair, if we stay in conversations with people who matter deeply. I do this for my family. M'sit No'kmaq, All my Relations.

\section{Acknowledgment}

Ethical citation of the all the visible and invisible kinship relationships that have shaped my worldview and stretched my heart is always my intention, as an imperfect human. The safe space and mentorship provided by $\mathrm{Dr}$ Vera Caine made this writing process a radical act of love. Deep gratitude to all who help us believe our stories matter. 


\section{References}

Aboriginal Nurses Association of Canada. (2001). An Aboriginal nursing specialty. Ottawa: Author.

Aboriginal Nurses Association of Canada. (2006a). Aboriginal health nursing project: Initiating dialogue. (Discussion Paper). Ottawa: Author. Aboriginal Nurses Association of Canada. (2006b). Best practices for the recruitment and retention of Aboriginal People into nursing education and nursing practice. Ottawa: Author.

Aboriginal Nurses Association of Canada, Canadian Association of Schools of Nursing, \& Canadian Nurses Association (2009). Cultural competence and cultural safety in nursing education: A framework for First Nations, Inuit and Métis nursing. Ottawa: ANAC.

Ahenakew, C.R. (2017). Mapping and complicating conversations about Indigenous education. Diaspora, Indigenous and Minority Education, 11(2), 80-91.

Allan, B. \& Smylie, J. (2015). First peoples, second class treatment: The role of racism in the health and wellbeing of Indigenous peoples in Canada. Toronto, ON: Wellesley Institute.

Anderson, J. R., Perry, J. R., Blue, C. R., Browne, A. R., Henderson, A. R., Khan, K. B., ... Smye, V. R. (2003). "Rewriting" cultural safety within the postcolonial and post national Feminist project: toward new epistemologies of healing. Advances in Nursing Science Health Variables: Economics and Class, 26(3), 196-214.

Augustine, S.J., (1999). Ethical guidelines on conducting research in Indigenous and local communities. [Unpublished draft report]. Dene Cultural Institute.

Baba, L. (2013). Cultural safety in First Nations, Inuit, and Métis public health: Environmental scan of cultural competency and safety in education, training and health services. Prince George, BC: National Collaborating Centre for Aboriginal Health.

Bhabha, H.K. (1994). The location of culture. London, UK: Routledge.

Bond, C. (2019). Being Indigenous... what does this mean? Lowitja Conference 2019. https://croakey.org/newreport-on-indigenous-healthresearch-from-lowitjaconf2019download-your-free-copy/

Bourque Bearskin, L. (2016). Through the lens of truth and reconciliation: Next steps. Canadian Nurse, 112(2), 36. https://www.canadiannurse.com/en/articles/issues $/ 2016 / \mathrm{m}$ arch-2016/through-the-lens-of-truthand-reconciliation-next-steps

Brooks-Cleator, L., Phillipps, B., \& Giles, A. (2018). Culturally safe health initiatives for Indigenous Peoples in Canada: a scoping review. Canadian Journal of Nursing Research, 50(4), 202-213. https://doi.org/10.1177/0844562118 770334

Browne, A. J. (2017). Moving beyond description: Closing the health equity gap by redressing racism impacting Indigenous populations. Social Science \& Medicine, 184, 2326.

DOI: 10.1016/j.socscimed.2017.04.0 45

Browne, A. J. (2005). Discourses influencing nurses' perceptions of First Nations patients. Canadian Journal of Nursing Research, 37(4), 62-87.

Browne, A. J., Smye, V. L., \& Varcoe, C. (2005). The relevance of postcolonial theoretical perspectives to research in Aboriginal health. Canadian Journal of Nursing Research, 37(4), 16-37.

Browne, A. J., Varcoe, C., Lavoie, J., Smye, V., Wong, S. T., Krause, M., 
Fridkin, A. (2016). Enhancing health care equity with indigenous populations: Evidence-based strategies from an ethnographic study. BMC Health Services Research, 16(1), 1-17. DOI: 10.1186/s12913-016-1707-9

Cajete, G. (1994). Look to the mountain: an ecology of Indigenous education. Durango, CO: Kivaki Press.

Canadian Association Schools of Nursing (2013). Educating nurses to address socio-cultural, historical, and contextual determinants of health among Aboriginal Peoples. https://www.casn.ca/2014/12/educat ing-nurses-address-socio-culturalhistorical-contextual-determinantshealth-among-aboriginal-peoples/

Canadian Association Schools of Nursing (2015). National nursing education framework. https://www.casn.ca/competencyguidelines/national-nursingeducation-framework/

Canadian Nurses Association (2010). Promoting cultural competence in nursing. Ottawa: Author.

Canadian Nurses Association (2014). Aboriginal health nursing and Aboriginal health: charting policy direction for nursing in Canada. Ottawa, ON: Author. https://www.cnaaiic.ca/ /media/cna/ page-content/pdf-en/aboriginalhealth-nursing- andaboriginalhealth_charting-policydirection-for-nursing-incanada.pdf?la=en

Chernomis, R., \& Hudson, I. (2010). Inequality as a cause of social murder. International Journal of Health Services, 40(1), 61-78.

Chin, M., Clarke, A., Nocon, R., Casey, A., Goddu, A., Keesecker, N., \& Cook, S. (2012). A roadmap and best practices for organizations to reduce racial and ethnic disparities in health care. Journal of General Internal Medicine, 27(8), 992-1000.

Chulach, T., \& Gagnon, M. (2016). Working in a "third space': A closer look at the hybridity, identity and agency of nurse practitioners. Nursing Inquiry, 23(1), 52-63.

Clifford, A., McCalman, J., Bainbridge, R., \& Tsey, K. (2015). Interventions to improve cultural competency in health care for Indigenous peoples of Australia, New Zealand, Canada and the USA: A systematic review. International Journal for Quality in Health Care, 27(2), 89-98. https://doi.org/10.1093/intqhe/mzv0 10

Doran, F., Wrigley, B., \& Lewis, S. (2019). Exploring cultural safety with Nurse Academics. Research findings suggest time to "step up." Contemporary Nurse, 55(2-3), 156170.

https://doi.org/10.1080/10376178.20 19.1640619

Ermine, W. (2007). The ethical space of engagement. Indigenous Law Journal, 6(1), 194-201.

Foth, T., \& Holmes, D. (2016). Neoliberalism and the government of nursing through competencybased education. Nursing Inquiry, 24(2), 1-9. https://doi.org/10.1111/nin.12154

Drevdalhl, D., Canales, M.K., \& Dorcy, S. Denise (2008). Of goldfish tanks and moonlight tricks: can cultural competency ameliorate health disparities? Advances in Nursing Science, 31(1), 13-27.

Gallagher, R. W., \& Polanin, J. R. (2015). A meta-analysis of educational interventions designed to enhance cultural competence in professional nurses and nursing students. Nurse Education Today, 35(2), 333-340.

Gaudry, A., \& Lorenz, D. (2018). Indigenization as inclusion, reconciliation and decolonization: Navigating the different visions for indigenizing the Canadian Academy. AlterNative, 14(3), 218 227. https://doi.org/10.1177/1771801187 85382

Gerlach, A. J. (2012). A critical reflection on the concept of cultural safety. Canadian Journal of Occupational 
Therapy, 79(3), 151-158. https://doi.org/10.2182/cjot.2012.79. 3.4

Goodman, B. (204). Paulo Freire and the pedagogy of the oppressed. Nurse Educations Today, 34(7), 10551056. https://doi.org/10.1016/j.nedt.2014.0 3.018

Government of Canada (1969). Statement of the Government of Canada on Indian policy (The White Paper, 1969) [Report]. https://www.aadncaandc.gc.ca/eng/1100100010189/11 00100010191

Gregory, D., \& Harrowing, J. (2012). Indigenous people's health and health-care equity: seven years later. Canadian Journal of Nursing Research, 44(2), p 15-18.

Guerra, O., \& Kurtz, D. (2017). Building collaboration: a scoping review of cultural competency and safety education and training for healthcare students and professionals in Canada. Teaching and Learning in Medicine, 29(2), 129-142. https://doi.org/10.1080/10401334.20 16.1234960

Hawkins, N. (2018). Self-preservation [illustration]. Expressions clinician wellbeing. An Art Exhibition. Washington, DC: National Academy of Medicine.

https://nam.edu/expressclinicianwell being/\#/artwork/186

Horvat, L., Horey, D., Romios, P., \& KisRigo, J. (2014). Cultural competence education for health professionals. Cochrane Database of Systematic Reviews, 5(5). https://doi.org/10.1002/14651858.C D009405.pub2

hooks, b. (2001). All about love: New visions. New York: William Morrow.

Jennings, W., Bond, C., \& Hill, P. S. (2018). The power of talk and power in talk: A systematic review of Indigenous narratives of culturally safe healthcare communication. Australian Journal of Primary
Healthcare, 24, 109-115. https://doi.org/10-1071/PYI 17082

Joseph, R. P. C. (2018). 21 things you might not know about the Indian Act. Vancouver, BC: Indigenous Relations Press.

Kimmerer, R. W. (2013). Braiding sweetgrass. Minneapolis, MN: Milkweed Productions.

Kovach, M. (2009). Indigenous methodologies. Toronto, ON: University of Toronto Press.

Kulig, J., Kilpatrick, K., Moffit, P., \& Simmers, I. (2013). Rural and remote practice: an updated documentary analysis. Lethbridge, AB: University of Lethbridge.

Kulig, J., Kilpatrick, K., Moffit, P., \& Zimmer, L. (2015). Recruitment and Retention in Rural Nursing: It's still and issue. Nursing Research, 28(2).

Churchill, M., Parent-Bergeron, M., Smylie, J., Ward, C., Fridken, A. \& Smylie, D. (2017). Evidence brief: wise practices for Indigenous-specific cultural safety training programs. Toronto, ON: Well Living House Action Research Centre for Indigenous Infant, Child and Family Health and Wellbeing., St. Michael's Hospital.

McCallum, M. J. L. (2018). Structures of indifference: An Indigenous life and death in a Canadian city. Winnipeg MB: University of Manitoba Press.

McCallum, M. J. (2014). Indigenous women, work, and history, 1940-1980. Winnipeg, MB: University of Manitoba Press.

McGibbon, E.A., Fhumalani, M., Didham, P., Barton, S., \& Sochan, A. (2014). Toward decolonizing nursing: the colonization of nursing and strategies for increasing the counternarrative. Nursing Inquiry, 21(3), 179-91.

McGregor, D. (2012). Indigenous women, water justice and Zaagidowin (Love). Canadian Woman Studies, 30(2), p. 71-78.

Million, D. (2013). Therapeutic Nations: Healing in an age of Indigenous 
human rights. Tucson, AZ: The University of Arizona Press.

Million, D. (2009). Felt theory: an Indigenous feminist approach to affect and history. Native Feminism, 24(2), p. 53-76.

Nakata, M. (2007). Disciplining the savages: savaging the disciplines. Canberra, AU: Aboriginal Studies Press.

Nakata, M. (2006). Australian Indigenous studies: A question of discipline. The Australian Journal of Anthropology, 17(3), 265-273.

Pratt, M.B. (1983). Identity: skin blood, heart. Women's Studies Quarterly, 11(3), 16.

Racine, L., \& Petrucka, P. (2011).

Enhancing decolonization and knowledge transfer in nursing research with non-western populations: Examining the congruence between primary healthcare and postcolonial feminist approaches. Nursing Inquiry, 18(1)., 12- 20.

Ramsden, I.M. (2002). Cultural safety and nursing education in Aotearoa and Te Waipounamu (Volume I-III). [Unpublished doctoral thesis]. Victoria University of Wellington.

Schick, C., \& St. Denis, V. (2005). Troubling national discourses in anti-racist curricular planning. Canadian Journal of Education, 28(3), 295-317.

Sheppard, D.M. (2019). Kesultultinij [video]. Vimeo. https://vimeopro.com/user20653208 lcbu

Simpson, L. (2013). Islands of decolonial love. Winnipeg, MB: Arbeiter Ring Publishing.

Stafford, W. (1998). A ritual to read to each other. The way it is: new \& selected poems. Saint Paul, MN: Graywolf Press.

Stansfield, D., \& Browne, A. J. (2013). The relevance of indigenous knowledge for nursing curriculum.

International Journal of Nursing

Education Scholarship, 10(1), 143-

151. doi:10.1515/ijnes-2012-0041
Truong, M., Paradis, Y., \& Priest, N. (2014). Interventions to improve cultural competency in healthcare: A systematic review of reviews. BMC Health Services Research, 14(1), 99. https://doi.org/10.1186/1472-696314-99

Truth and Reconciliation Commission of Canada (2015). Truth and Reconciliation Commission of Canada: Calls to action. Winnipeg, MB: Author. http://trc.ca/assets/pdf/Calls_to_Acti on_English2.pdf

Vukic, A., Jesty, C., Mathews, V., \& Etowa, J. (2012). Understanding race and racism in Nursing: insights from Aboriginal nurses. International Scholarly Research Network. Doi:10.5402/2012/196437.

Ward, C., Branch, C. \& Fridkin, A. (2016). What is Indigenous cultural safetyand why should I care about it? Visions: BC's Mental Health and Substance Use Journal, 11(4), 29.

Whiteduck, M. (2013). "But it's our story. Read it.": Stories my grandfather told me and writing for continuance. Decolonization: Indigeneity, Education \& Society, 2(1), 72-92.

Youngblood Henderson, J.S. (2000). Ayukpachi: empowering Aboriginal thought. In Reclaiming Indigenous voice and vision, Battiste, $\mathrm{M}$. Ed. Vancouver, BC: UBC press.

Younging, G. (2018). Elements of Indigenous style: A guide for writing by and about Indigenous peoples. Edmonton, $\mathrm{AB}$ : Brush Education. 